\title{
SPIRITUALITAS KARAKTER TUANG DALAM BUDAYA MASYARAKAT KAMPUNG ADAT CIREUNDEU
}

\author{
U. Abdullah Mu'min \\ STAI Pelabuhan Ratu, Email: Abdullahmukmin77@gmail.com
}

\begin{abstract}
ABSTRAK
Bagi masyarakat adat, prilaku makan atau tuang dalam bahasa Sunda tidak hanya berorientasi jasmaniah. Ada nilai-nilai khusus yang kemudian dijadikan entitas keyakinan yang mentradisi. Terlebih menjadikan singkong sebagai makanan pokok masyarakatnya. Penelitian ini bertujuan untuk mengungkap makna tuang bagi masyarakat Cireundeu. Tuang tidak sekedar bahasa simbolik, namum mengandung makna budaya, tradisi, adat istiadat bahkan ritual adat. Penelitian ini menggunakan pendekatan kualitatif dengan metode studi kasus. Pengumpulan data melalui observasi, wawancara, dokumentasi dan studi literatur. Dihasilkan dari penelitian ini, tuang dimaknai bukan sekedar hajat jasmaniah semata, tapi hakikat-nya sumber kekuatan spiritual. Istilah teu dahar asal kuat, bermakna filosofis sebagai sumber kekuatan, kehidupan, dan kemandirian bagi masyarakat Cireundeu. Tuang membawa makna mendalam dalam membangun karakter pasrah atas keadaan diri untuk mempertahankan godaan manusia dari dua hal; si ujang (duit), si nyai (beras). Godaan-godaan lingkungan harus dijaga, agar kelestarian dan keunikan suatu entitas kampung adat tetap terpelihara.
\end{abstract}

Kata kunci : Spiritualitas; Karakter; Tuang; Budaya

\begin{abstract}
For indigenous peoples, the behavior of eating or tuang in Sundanese is not only physically oriented. There are special values which are then made into a belief entity that is a derivative. Especially making cassava as a staple food for the people. This research aims to reveal the meaning of Tuang for the people of Cireundeu. Tuang is not just a symbolic language, but contains the meaning of culture, tradition, customs and even traditional rituals. This research uses a qualitative approach by case study method. Collecting data through observation, interviews, documentation and literature studies. As a result of this research, The term tuang is not just as a physical necessity but the essence of the source of spiritual strength. The term "teu dahar asal kuat" as philosophical meaning is a source of strength, life, and independence for the people of Cireundeu. Tuang brings deep meaning in building resigned character over the state of self that can defend human temptation from two things; si ujang (money), si nyai (rice). The Environmental temptations that must be guarded, so that the sustainability and uniqueness of a traditional village entity is maintained.
\end{abstract}

Keywords: Spirituality; Character; Eating; Culture 


\section{PENDAHULUAN}

Setiap makhluk hidup membutuhkan makanan. Tanpa makanan, makhluk hidup akan sulit dalam mengerjakan aktivitas kesehariannya. Makanan dapat membantu untuk mendapatkan energi serta membantu pertumbuhan badan dan otak. Memakan makanan yang bergizi akan membantu pertumbuhan setiap makhluk hidup agar dapat menumbuhkan potensi dan eksistensinya dalam kehidupan.

Makan bagi sebagian besar orang dimaknai pemenuhan hajat jasmani demi kekuatan fisik yang sehat. Namun ada kalanya makanan dijadikan sebagai alat kesombongan untuk pamer, kekikiran, pelampiasan nafsu, dan alat untuk menzalimi orang lain. Sebagai sebuah media pemenuhan prestise, kadang makan dijadikan landasan eksistensi dan status hidup seseorang. Semakin bergengsi tempat dan menu makan yang dikonsumsi, makin kentara pendikotomian status dan tingkat kepercayadirian seseorang.

Makan dalam perspektif budaya dipahami sebagai suatu aktivitas menonjol yang menentukan interaksi sosial, berkaitan dengan kepercayaan dan agama, menentukan bentuk atau pola ekonomi, dan mengarahkan sebagian besar aktivitas kehidupan sehari-hari manusia (Fadhilah, 2014). Peran makanan dalam kebudayaan merupakan kegiatan ekspresif yang memperkuat kembali hubungan-hubungan dengan kehidupan sosial, sanksi-sanksi, agama, ekonomi, ilmu pengetahuan, teknologi dengan berbagai dampaknya. Dengan kata lain, kebiasaan makan atau pola makan tidak hanya sekadar mengatasi tubuh manusia saja, melainkan dapat memainkan peranan penting dan mendasar terhadap ciri-ciri dan hakikat budaya makan (Meliono-Budianto, 2004). Karena itu, makanan yang dikonsumsi, bukan hanya berfungsi sebagai sumber zat gizi, melainkan juga mampu mempengaruhi penampilan serta mencegah dan mengurangi resiko penyakit (Silalahi, 2006, p. 15).

Studi tentang makanan dalam konteks budaya seringkali merujuk pada persoalan-persoalan praktis serta perilaku konkret masyarakatnya. Tak jarang makanan dipersepsikan dengan nilai sakralitas karena mengandung unsur mistis dan kepercayaan masyarakatnya. Akibatnya, kepercayaan suatu masyarakat tentang makanan tidak hanya sekedar berakibat pada kebiasaaan pola konsumtif, tapi lebih dari itu ada nilai historis yang kemudian menjelma pada satu tradisi. Tak jarang, nilai spiritualitas mempengaruhi membentuk kebermaknaan suatu nilai tradisi adat.

Menurut Tjetjep Rohendi sebagaimana dikutip Setiawan Sabana (Sabana, 2007) diuraikan :

"Dalam perspektif antropologi, khususnya budaya, makanan bukanlan sesuatu yang dipandang semata-mata berhubungan dengan aspek fisiologis dan biologis manusia melainkan secara menyeluruh terserap dalam suatu sistem budaya makanan. Sistem budaya makanan mencakup kegiatan produksi, distribusi, dan konsumsi makanan yang di dalamnya tersirat pemenuhan kebutuhan manusia --primer, sosial, dan budaya-- dalam rangka melangsungkan kehidupan dan meningkatkan kesejahteraan 
diri, keluarga, dan masyarakatnya, dihadapkan pada sumber daya lingkungan alam (juga sosial-budaya) yang dapat dimanfaatkannya".

Dalam kajian antropologi kebiasaan makan sebagai sesuatu yang sangat kompleks karena menyangkut tentang cara memasak, suka dan tidak suka, serta adanya berbagai kepercayaan (religi), pantangan-pantangan dan persepsi mitis (tahayul) yang berkaitan dengan kategori makan: produksi, persiapan dan konsumsi makanan (Foster, 1986, p.313). Karena itu, dalam perkembangannnya, kategori makan akan dan berkaitan dengan kategori-kategori budaya lainnya seperti, kategori kehidupan sosial, agama, kehidupan perekonomian, ilmu pengetahuan, teknologi dan sebagainya. Dalam perspektif agama, makan dimaknai tidak hanya sekedar pemenuhan kebutuhan fisik, lebih dari itu bersentuhan langsung dengan nilai ruhani dan ibadah. Apresiasi agama terhadap proses makan, menjadikan tahapan selektif mulai dari input yang dimakan sampai output yang dihasilkan tidak lepas dari nilai ibadah. Makna spiritualitas ini menjadikan hubungan makan dengan eksistensi ketuhanan yang di dalamnya terkandung relasi ibadah transendental. Bahkan dalam Alquran disebutkan bagaimana hubungan perintah makan dengan perintah bertakwa. "Dan makanlah makanan yang halal lagi baik dari apa yang Allah telah rezkikan kepadamu, dan bertakwalah kepada Allah yang kamu beriman kepada-Nya (QS. Al-Maidah/5: 88).

Simbol spiritual ini memungkinkan lahirnya energi keyakinan diri, bahwa apa yang dimakan tidak hanya terkait sekedar pemenuhan rasa lapar dan kebutuhan rasa yang lezat, namun lebih menumbuhkan energi terbarukan menghasilkan semangat hidup menjalankan fungsi kemanusiaan. Perilaku yang kemudian membentuk karakter pribadi yang lebih mengedepankan makan hati daripada makanan badan. Sebagai kebutuhan pokok manusia, konsumsi makan selalu diupayakan mengandung energi untuk dapat beraktivitas. Idealnya menurut teori, manusia perlu makan 3 kali sehari untuk memenuhi kebutuhan gizinya agar bisa survive menjalani kehidupannya. Seiring dengan perubahan gaya hidup, saat ini manusia tidak hanya mengkonsumsi nasi selama makan sebagai kebutuhan pokok. Nasi sebagai sumber karbohidrat, bisa digantikan dengan sumber karbohidrat yang lain seperti singkong, kentang, roti, roti gandum, cereal, dan lain-lain.

Demikian halnya bagi kampung Cireundeu sebagai salah satu kampung adat yang ada di Jawa Barat, yang sebagian besar penduduknya sudah meninggalkan ketergantungannya pada beras sebagai makanan pokok sehari-hari. Mereka menjadikan singkong sebagai pilihannya yang telah terbukti menyelamatkan warganya dari krisis pangan yang terjadi. Keyakinan yang tumbuh mentradisi sebagai solusi kesulitan dan keterbatasan kebutuhan akan makanan pokok. Hal ini dapat dijadikan contoh yang dapat diimplementasikan di daerah lain sebagai bukti nyata program ketahanan pangan. 
Makan dalam istilah Sunda dibahasakan kata "tuang". Makna tuang bagi kampung Cireundeu, tidak hadir sekedar simbol bahasa, namun ada makna nilai-nilai filosofis, historis, sosiologis sampai ekonomis sebagai karakter eksistensi entitas suatu adat. Ketika singkong menjadi makanan pokok tradisi adat, akan muncul makna-makna karakteristik yang sangat menarik untuk diteliti.

\section{METODE PENELITIAN}

Penelitian ini adalah penelitian kualitatif. Penelitian kualitatif adalah proses penelitian untuk memahami berdasarkan tradisi metodologi penelitian tertentu dengan cara menyelidiki masalah sosial atau manusia. Peneliti membuat gambaran komplek bersifat holistik, menganalisis kata-kata melaporkan pandangan-pandangan para subjek penelitian secara rinci, dan melakukan penelitian dalam situasi alamiah (Creswel, 2009, p. 15).

Oleh karenanya, penelitian ini berupaya mengamati orang dalam lingkungan hidupnya berinteraksi dengan mereka, berusaha memahami bahasa dan tafsiran mereka tentang dunia sekitarnya. Dengan menggunakan kerangka berfikir tersebut, peneliti dimungkinkan untuk dapat berkomunikasi secara langsung dengan subjek penelitian serta dapat mengamatinya sejak awal sampai akhir proses penelitian. Fakta dan data hasil penelitian inilah yang nantinya oleh peneliti diberi makna sesuai dengan teori-teori yang relevan dengan pertanyaan penelitian (Nasution, 2003, p. 5).

Penelitian kualitatif ini menggunakan pendekatan deskriptif analitik yang akan menjabarkan dan menggambarkan temuan di lapangan selama waktu Maret-April 2019 berupa hasil olahan data yang sudah diperoleh mengenai makna tuang sebagai sebuah entitas sakralitas budaya masyarakat Cirendeu melalui pendekatan budaya dan antropologi.

\section{PEMBAHASAN}

Masyarakat desa adalah masyarakat yang kehidupannya masih banyak dikuasai oleh adat istiadat lama. Adat istiadat adalah sesuatu aturan yang sudah mantap dan mencakup segala konsepsi sistem budaya yang mengatur tindakan atau perbuatan manusia dalam kehidupan sosial hidup bersama, bekerja sama dan berhubungan erat secara tahan lama, dengan sifat-sifat yang hampir seragam. Nilai-nilai budaya dalam masyarakat partikular ditujukan hanya untuk diukur oleh budaya lokal, bukan oleh budaya luar. Hal ini berdasar alasan bahwa sesuatu yang dianggap baik bagi suatu komunitas belum tentu baik bagi komunitas lain. Karena nilai-nilai ini hanya dihasilkan oleh sebuah sistem lokal terhadap nilai-nilai budaya yang spesifik yang tidak bisa diukur dengan sistem dari budaya lain (Ambarwangi, Sri; Suharto, 2014).

Kampung adat Cirendeu merupakan perkampungan adat yang terletak di kota Cimahi. Biasanya lokasi kampung adat terletak jauh dari pusat kota tetapi tidak bagi 
kampung adat ini. Kampung adat Cireundeu memiliki keunikan dalam hal agama, makanan khas, dan mata pencaharian. Meskipun saat ini zaman sudah modern, mereka tetap mempertahankan tradisinya (Gustiani, Herawati Murti; Utami, Dian, 2017). Bahasa Cireundeu sendiri berasal dari nama "pohon reundeu", karena sebelumnya di kampung ini banyak sekali populasi pohon reundeu. Pohon reundeu adalah pohon yang biasa digunakan untuk obat herbal. Maka kampung ini disebut Kampung Cireundeu (Gunardi, Gugun; Mahdi, Sutiono; Ratnasari, Dewi; Sobarna, Cece, 2015). Kampung Cireundeu merupakan salah satu lokasi yang terletak di kelurahan Leuwigajah, Kecamatan Cimahi Selatan Kota Cimahi, hal ini berdasarkan Undang-undang No.1 Tahun 2001 tentang Pembentukan Kota Cimahi. Secara geogafis, letak perkampungan Cireundeu berada di perbatasan Kota Cimahi dengan Kabupaten Bandung Barat tepatnya dengan Kecamatan Batujajar. Jarak dari kampung Cireundeu ke Kelurahan Leuwigajah sekitar $3 \mathrm{Km}$, dan $4 \mathrm{Km}$ ke kecamatan serta $6 \mathrm{Km}$ ke kota atau pemerintah kota Cimahi.

Sebagai komunitas masyarakat adat, Kampung Cireundeu menekankan entitas adat kesundaan dengan memelihara serta melestarikan adat istiadat secara turun temurun. Diantara kebiasaan unik yang diberlakukan sampai saat ini, adalah diwajibkannya semua warga kampung Cireundeu penganut budaya Pasundan untuk bisa menulis dan paham huruf aksara sunda dan untuk itu, setiap hari selalu ada pelajaran aksara sunda yang diajarkan kepada anak-anak, dengan alasan "urang sunda adatna kudu sunda. Urang Teh Ulah Cul Dogdog Tinggal Igel, Jati Kasilih Kujunti”, yang artinya kita jangan sampai terpengaruhi oleh budaya luar, sementara budaya sendiri dilupakan. Orang Sunda harus berperilaku orang sunda, harus bisa aksara Sunda, adatnya pun seharusnya adat sunda. Ditunjang karakteristik masyarakat yang sangat kental mempertahankan tradisi ke-Sunda-an dan mampu memelihara, melestarikan adat istiadat secara turun temurun dan tidak terpengaruhi oleh budaya dari luar. Suasana kehidupan perkampungan sangat terasa penuh kedamaian dan kerukunan yang dibingkai dalam filosofi kehidupannya "silih asah, silih asih, silih asuh, tata, titi, duduga peryoga".

Kampung adat yang dihuni $358 \mathrm{KK}$ atau 1552 jiwa, tersebar dalam 5 wilayah ke RT-an, merupakan kelompok masyarakat yang memiliki kebiasaan makan yang berbeda, yang mengkonsumsi onggok singkong atau beras singkong (rasi) sebagai makanan pokok (staple food). Kebiasaan ini ber-beda dengan kelompok masyarakat Jawa Barat yang umumnya mengkonsumsi be-ras sebagai makanan pokok. Alasan lain masyarakat mengkonsumsi "rasi" adalah karena aliran kepercayaan yang di-anutnya, yang mewajibkan pengikutnya mengkonsumsi makanan non beras (Putranto, Keik; Taofik, Ahmad, 2014).

Kampung Cireundeu mempunyai filosofi kehidupan yang sangat unik, masyarakat masih mempertahankan adat leluhurnya; dari segi keyakinan 
menjadikan Sunda Wiwitan sebagai keyakinan serta menjadikan makanan pokoknya nasi yang terbuat dari singkong atau dikenal dengan nama "Rasi" atau beras singkong, bahkan diverifikasi produk makanan yang berbahan dasar singkong ke dalam jenis makanan lainnya (Emen, 2019). Ini menjadi pertanda kuat karakteristik masyarakat Cirendeu menjadi terkenal karena sebagian besar masyarakatnya memilih Rasi sebagai makanan pokoknya dan menjadikan Sunda Wiwitan sebagai suatu kepercayaan (Nurhayanto, Puji; Wildan, Dadan; Alia, Mirna Nur, 2016).

Sejak zaman nenek moyang (karuhun) tepatnya tahun 1918, mereka sudah menghilangkan tradisi memakan nasi beras, dan beralih mengkonsumsi ubi kayu (singkong) sebagai makanan pokok. Menurutnya, singkong lebih mudah ditanam dah dihasilkan di daerahnya yang sangat subur, sehingga tidak akan merasa kekurangan makanan dibanding dengan nasi beras. Sikap kemandirian yang menjadikan mereka merasa hidup lebih tentram tanpa terpengaruhi oleh fluktuasi harga bahkan sampai krisis ekonomi. Oleh karenanya, mereka selalu memegang teguh pepatah Karuhun Cireundeu, yaitu: "Teu Nyawah asal boga Pare, Teu boga Pare asal boga Beas, Teu boga Beas asal Bisa Nyangu, teu Nyangu asal Dahar, teu dahar asal Kuat" (Widi, Filosofi Masyarakat Cireundeu, 2019). Maksudnya; tidak punya sawah asal punya beras, tidak punya beras asal dapat menanak nasi, tidak punya nasi asal makan, tidak makan asal kuat. Kekuatan adalah sumber segalanya dengan menyandarkan diri pada kekuatan yang memiliki, yaitu Tuhan Yang Maha Esa.

Beralihnya makanan pokok masyarakat adat kampung Cireundeu, dipelopori oleh Ibu Omah Asmanah, putra Bapak Haji Ali yang kemudian diikuti oleh saudara-saudaranya di kampung Cireundeu. Ibu Omah Asmanah mulai mengembangkan makanan pokok non beras ini. Berkat kerja keras dan usahanya ini, pada tahun 1964, pemerintah melalui Wedana Cimahi memberikan penghargaan sebagai "Pahlawan Pangan".

Pada masa tugas Bupati Memed yang mempunyai perhatian besar terhadap makanan pokok singkong, makanan pokok penduduk kampung Cireundeu tersebut sering diikutsertakan pada pameran-pameran makanan non beras yang mewakili Kabupaten Bandung. Salah satu tujuan diperkenalkannya berbagai jenis makanan yang terbuat dari singkong dan proses pembuatan nasi singkong adalah agar masyarakat pada umumnya tidak tergantung pada beras sebagai makanan pokok. Artinya, ada alternatif bahan pokok yang bisa dikonsumsi bahkan sangat mudah mendapatkan bahannya.

Munculnya beragam perhatian dan mudahnya mendapatkan bahan ubi kayu (singkong), menumbuhkan siasat peluang yang membawanya pada usaha keanekaragaman pengolahan hasil dari ubi kayu tersebut, diantaranya dapat dibuat Rangginang, Bugis, Awug, Beras Singkong (Rasi), dan lain-lain. Makanan-makanan tersebut biasanya diolah oleh para ibu masyarakat adat karena pada umumnya 
mereka lebih banyak diam di rumah, sedangkan para bapak/suami pergi ke gunung untuk bertani dan beternak.

Potensi kegiatan pengolahan singkong yang dilakukan oleh warga kampung Cireundeu pada prinsipnya dapat meningkatkan perekonomian komunitas secara signifikan dibandingkan dengan hanya menjual singkong dalam kondisi bahan mentah. Bahkan dalam perkembangannya, olahan singkong dikembangkan menjadi media industri usaha, mulai dari akarnya hingga daunnya. Akarnya diolah menjadi rasi (beras singkong), rangening, opak, kecimpring, peuyeum atau tape, dan aneka kue berbahan dasar singkong (seperti kue keju, kue lidah kucing, agg rolls, dan sebagainya). Batangnya dimanfaatkan menjadi bibit. Daunnya dijadikan lalapan atau disayur dan kadang dapat dijadikan makanan ternak. Terakhir kulitnya dibuat menjadi makanan olahan, biasanya dijadikan sayur lodeh atau dengdeng kulit singkong. Selain untuk dikonsumsi sendiri hasilnya juga dapat dijual pada wisatawan sebagai buah tangan yang memiliki nilai jual tinggi. Singkong di kampung Cireundeu dapat dibuat menjadi berbagai macam makanan dengan berbagai menu pilihan. Bahkan dalam sebuah penelitian (Gulfa, 2015), kampung Adat Cireundeu kini sedang dikembangkan oleh Pemerintah Kota Cimahi menjadi Desa Wisata ketahanan pangan, adalah Kampung Adat Swasembada pangan karena swasembada pangan memiliki definisi yaitu kemampuan untuk memenuhi kebutuhan-kebutuhan bahan makanan sendiri tanpa perlu mendatangkan dari pihak luar.

Adapun aturan dalam memproduksi singkong ini harus ditanam pada lahan yang sudah tersedia dan ditentukan oleh pemangku adat. Lahan yang terdapat di hutan tersebut terdiri dari lahan garapan produktif dan lahan larangan. Lahan garapan produktif inilah yang digunakan masyarakat untuk bercocok tanam terutama ubi kayu (singkong). Sedangkan lahan larangan merupakan penyeimbang lahan dan tidak boleh ditanam oleh apapun dan siapapun. Hal ini juga dimaksudkan untuk menghindari bahaya bencana alam yang dikhawatirkan menimpa ke wilayah pemukiman warga.

Kepedulian dan kecintaannya terhadap alam dan lingkungan sekitar menjadi bagian dari kehidupan warga, sebagai impelementasi menjaga petuah leluhurnya dengan mewarisi ungkapan Sunda sebagai berikut: "Gunung Kaian, Gawir Awian, Cinyusu Rumateun, Sampalan Kebonan, Pasir Talunan, Dataran Sawahan, Lebak Caian, Legok Balongan, Situ Pulasareun, Lembur Uruseun, Walungan Rawateun, jeng Basisir Rawateun" (Widi, Perspektif Alam dan Lingkungan, 2019). Refleksi sikap kearifan budaya lokal yang selalu diterapkan di lingkungan masyarakat adat kampung Cireundeu. Demikian halnya bagi kampung Cireundeu, sakralitas budaya sebagai entitas adat selalu dilestarikan, sekalipun tantangan dan rintangan dari gerusan budaya luar sangat kuat. Bagi mereka, melestarikan budaya sebagai tradisi dan adat istiadat adalah keharusan untuk menjaga kelangsungan hidup 
masyarakatnya.

Tradisi-tradisi yang dilestarikan sebagai budaya, nampaknya sejalan dengan pandangan Mardimin bahwa masyarakat terus menerus menciptakan suatu karya cipta, penetapan, dan pola laku. Penetapan dan prilaku ini akan menciptkan suatu tradisi yang diwariskan dari generasi ke generasi dan dilaksanakan secara turun temurun dari nenek moyang mereka. Pada umumnya tradisi sering disebut sebagai sesuatu yang statis, mistis, dan mitologis. Meski demikian, tradisi yang ada dalam negeri ini merupakan cara untuk mempererat jalinan pribadi antar masyarakat. Tradisi bukanlah suatu obyek yang mati tetapi alat yang hidup untuk melayani manusia (Mardimin, 1994).

Tradisi berarti adat kebiasaan turun temurun (dari nenek moyang) yang masih dijalankan dalam masyarakat. Bisa juga diartikan penilaian atau anggapan bahwa cara-cara yang telah ada merupakan yang paling baik dan benar (Depdikbud, 2005). Kata lain yang memiliki makna hampir sama adalah budaya. Tradisi sering dibahasakan dengan adat istiadat. Terdapat beberapa hal yang berkaitan erat dengan tradisi. Pertama adalah karakter, kedua adalah kondisi geografis. Semua tradisi adalah sesuatu yang diciptakan. Tradisi serta adat istiadat tercipta karena berbagai alasan (Muhakamurrohman, 2014).

Tradisi dipengaruhi oleh kecenderungan untuk berbuat sesuatu dan mengulang sesuatu sehingga menjadi kebiasaan. Kebiasaan baik akan diakui dan dilaksanakan oleh orang banyak yang kemudian dijadikan dasar bagi hubungan antara orang-orang tertentu sehingga perbuatan itu menimbulkan tatanan nilai, norma, atau kaidah yang disebut adat istiadat (Daeng, 2002). Tradisi-tradisi tersebut akan selalu berinteraksi, baik secara internal maupun eksternal dengan budaya lain. Sistem penguatan budaya dilakukan untuk menjaga kelangsungan masyarakat terutama menjaga potensi konflik benturan budaya dan tradisi. Pritim A. Sorokin menyatakan:

"Sistem berlapis-lapis merupakan ciri yang tetap dan umum dalam setiap masyarakat yang hidup teratur, seperti yang terjadi pada desa. Hal tersebut menyebabkan stratifikasi sosial yang melekat pada desa. Stratifikasi sosial dapat dipengaruhi oleh kekuasaan dan peran yang terdapat dalam kedudukan sosial seseorang. Faktor-faktor yang menjadi ukuran atau kriteria sebagai dasar pembentukan dasar pelapisan sosial yaitu, ukuran kekayaan, ukuran kekuasaan dan wewenang, ukuran kehormatan, dan ukuran ilmu pengetahuan. Kedudukan sosial merupakan tempat seseorang secara umum dalam masyarakatnya yang berhubungan dengan orang lain, dalam arti lingkungan pergaulannya, prestisenya, dan hak-hak serta kewajiban-kewajibannya (Douglas, 1981).

Interaksi sosial merupakan kunci dari semua kehidupan sosial, karena tanpa interaksi sosial tak akan mungkin ada kehidupan bersama. Bentuk umum proses sosial adalah interaksi sosial (yang juga dapat dinamakan sebagai proses sosial) karena interaksi sosial merupakan syarat utama terjadinya aktivitas-aktivitas sosial. 
Interaksi sosial merupakan hubungan-hubungan sosial yang dinamis yang menyangkut hubungan antara orang-orang perorangan, antara kelompok-kelompok manusia, maupun antara perorangan dengan kelompok manusia. Interaksi sosial menjelaskan proses pembentukan nilai, norma, dan adat. Proses ini tak lepas dari pewarisan kelompok manusia atau masyarakat yang menjadi pendahulunya. Berlangsung suatu proses interaksi didasarkan pada berbagai faktor (Soekanto, 1987).

Berdasarkan hasil penelitian, Masyarakat Kampung Adat Cireundeu memiliki keadaan sosial yang terbuka dengan masyarakat di luar kampung, sehingga interaksi sosial yang terjadi di Kampung Cireundeu berlangsung dengan sangat terbuka. Dapat dikatakan mereka merupakan masyarakat kampung adat yang fleksibel. Berbeda dengan interaksi sosial di kampung-kampung adat lainnya yang sangat tertutup dan dengan keras menolak masuknya teknologi modern ke kampung mereka, misalnya saja interaksi sosial pada masyarakat Kampung Dukuh, Kampung Naga, Kampung Pulo, dan sebagainya. Dalam kehidupan sehari-hari, mereka menerapkan tatakrama kehidupan bermasyarakat dengan prinsip silih asah, silih asih, silih asuh, tata, titi, duduga peryoga", dengan menjungjung rasa kekeluargaan yang dimulai dengan saling mengenal satu sama lain, kemudian saling mengasihi dan menyayangi, dan berlanjut dengan saling menjaga/memelihara, saling membutuhkan dan membantu sehingga tercipta masyarakat adat yang "akur, rukun, repeh, rapih, sareng sasama hirup".

Mereka semua hidup berdampingan, bahkan kesan kebersamaan dan gotong royongnya sangat kuat dibandingkan dengan kawasan lain sekitarnya. Mereka tidak hidup individulistis juga tak mengenal kata perorangan, saling membantu sama lain yang mereka prioritaskan. Hal tersebut menjadikan situasi kehidupan penuh kedamaian dan kerukunan betul-betul terjelma di kampung yang nan jauh dari keramaian kota.

Sebagai kampung yang dinobatkan sebagai salah satu kampung adat yang ada di Jawa Barat, Kampung Cireundeu tidak menutup diri dari perkembangan teknologi yang sangat pesat sekarang ini. Dalam batasan-batasan tertentu mereka secara terbuka menerima teknologi di tengah-tengah kehidupannya, tanpa melupakan adat leluhurnya. Bagi mereka menjaga apa yang yang telah diwariskan oleh para leluhurnya, bukan berarti tidak boleh bergaul dengan yang lainnya. Apalagi sampai menutup diri dari perkembangan zaman.

Salah satu faktor utama yang menyebabkan adanya sikap keterbukaan tersebut yaitu, letak kampung Cireundeu itu sendiri yang tidak jauh dari Kota tepatnya di perbatasan kota Cimahi. Sehingga arus modernisasi dari kota dapat dengan mudah masuk ke kampung mereka. Adapun bukti dari sikap keterbukaan mereka terhadap kemajuan teknologi dapat terlihat dalam beberapa fakta yang kami temukan di lapangan diantaranya; bentuk bangunan rumah yang permanen dengan bentuk dan 
ukuran yang tidak sama. Sehingga memberikan kesan pertama bahwa suasana Kampung Cirendeu tidak jauh beda dengan perkampungan lainnya, dan tidak menampakan layaknya kampung adat.

Cara berpakaian mereka sangat rapi bahkan modis. Penggunaaan atribut adat nampaknya hanya berlaku bagi kalangan orang tua utamanya pemangku adat. Sedangkan anggota adat lainnya khususnya dari kalangan anak muda menggunakan pakaian laiknya masyarakat biasa lainnya.

Alat-alat rumah tangga yang digunakan-pun sudah modern, seperti kompor gas, dispenser, kulkas, dan lain-lain. Termasuk juga penggunan alat-alat komunikasi dan telekomunikasi yang digunakan berupa televisi, handphone, radio, dan lain-lain. Bahkan sebagian besar anak mudanya sudah mengenal internet. Dalam hal pernikahan, anggota warga adat tidak diwajibkan menikah dengan warga setempat. Sehingga mereka bisa memilih sesuai kehendaknya sekalipun berbeda pandangan dalam konsumsi singkong. Nampak di lapangan, ada sebagian warga adat yang menikah dengan warga kampung lainnya, dan berbeda konsumsi makanan pokok-nya; yang satu singkong, dan lainnya kadang nasi.

Kelompok yang disebut pendatang melalui garis perkawinan ini, sejatinya beradaptasi dengan adat dan kebiasaan masyarakat Cireundeu. Mereka dituntut mengikuti kebiasaan makan rasi (beras singkong), hal ini bertujuan menghargai kebiasaan atau adat istiadat nenek moyang terdahulu. Namun kenyataannya saat ini, tidak dapat dipungkiri masih mempertahankan tradisi lama dengan tetap memakan nasi beras. Karakteristik masyarakat biasa, tidak terkategori sebagai masyarakat adat. Hal ini menjadikan tidak adanya paksaan dalam mengkonsumsi makanan pokok rasi, khususnya bagi masyarakat pendatang.

Oleh karena itu, tradisi masyarakat adat kampung Cireundeu pada dasarnya sangat berbeda dengan masyarakat adat lainnya yang kuat pada keyakinan adat istiadat yang sudah ditentukan dan mutlak harus dilakukan. Norma atau kaidah-kaidah yang terdapat dalam adat-istiadat pada masyarakat adat ini dalam bertingkah laku atau bertindak sebenarnya tidak terpaku pada aturan atau norma yang tertulis secara khusus, akan tetapi bersifat tidak tertulis dan dipelihara secara turun-temurun. Masyarakat hanya mengikuti tindakan yang dilakukan nenek moyang terdahulu dalam kebiasaan-kebiasaannya yang terpacu pada adat atau kebiasaan dalam hal masalah pangan, yaitu mengenai makanan pokok.

Istilah kata "Dipigawe Bakal Ngaraksuk, Dilanggar Bakal Ngaruksak", menggariskan meskipun masyarakat adat Cireundeu ini kehidupannya sudah modern, tetapi tidak pernah meninggalkan atau menghilangkan adat-istiadat yang diwariskan nenek moyangnya terdahulu, artinya adat-istiadatnya tetap dipertahankan serta mengikuti perkembangan zaman yang dapat disebut "ciri wanci, cara wangsa". Istilah "pamali" merupakan bentuk kehati-hatian dari aspek larangan 
yang harus dijauhi sebagai bagian dari konservasi adat. Jika pelanggaran terjadi, secara otomatis ada hukum adat; mulai dianteup sampai diusir (Jajat, 2019). Ini menegaskan relasi agama dan lingkungan. Menjaga kelestarian alam merupakan media untuk mencapai puncak religiusitas dalam melaksanakan ritus aliran dan kepercayaannya. Keadaan ini memungkinkan terciptanya suatu hubungan erat antara manusia dan alam.

Di samping itu, penghayatan Sunda Pasundan yang menjadikan ubi kayu (singkong) sebagai makanan pokok utama merupakan warisan yang diturunkan turun-temurun oleh nenek moyang terdahulu yang tidak boleh hilang meskipun Kampung Cireundeu ini berada ditengah-tengah kota Cimahi yang sudah berpotensi tergerus dengan kebudayaan luar. Peter Siena (2012) memaknai situasi tersebut dengan uraian:

"Makan sebagai memahami orang lain dan diri sendiri secara keseluruhan yang berlandaskan kebijaksanaan atau nilai-nilai kearifan. Dengan demikian definisi filsafat makan dengan cara membangun genus proximum serta differentia specifica secara independen, karena penulis menimbang adanya kesesuaian dengan dua hal pokok yaitu no free lunch alias tak ada makan siang gratis, dan kedua adalah pemahaman hari ini makan apa dan besok makan siapa. Pertimbangan dua hal pokok ini akan mengarahkan pada kepekaan atau sensitifitas diri terhadap diri sendiri dan orang lain. Maksudnya adalah bagaimana filsafat makan akan mengkaji secara mendalam tentang bagaimana menghargai diri sendiri dan bertanggung jawab terhadap diri serta bagaimana melaksanakan tanggung jawab moral terhadap sesama dan sang Pencipta" (Siena, 2017).

Dalam kajian filsafat, makan akan memfokuskan pada bagaimana seseorang bersikap dengan benar dan baik tentang bagaimana membangun keyakinan positif serta tidak mengkambinghitamkan orang lain untuk mencari posisi aman bagi dirinya. Dengan memahami filsafat makan maka seseorang akan memahami arti kerja keras dan kerja cerdas sehingga terhindar dari suka mengambil hak orang lain secara picik atau tidak beretika, melainkan bagaimana mengajarkan seseorang untuk mau berupaya untuk mewujudkan sesuatu atau berupaya sekuat tenaga atau sungguh-sungguh untuk mendapatkan hasil sehingga kepuasan diri dapat dialami.

Tidak hanya itu saja, filsafat makan juga akan menjadi suatu alat untuk lebih mampu mengasah kepekaan jiwa yang sebenarnya merupakan salah satu faktor pembeda manusia dan makluk lainnya. Nalarnya adalah pemahaman filsafat makan yang tepat akan mendorong seseorang berani menolak dengan tegas terhadap perbuatan-perbuatan yang merugikan orang lain dan dengan tulus ikhlas menerima kenyataan bahwa dirinya dan orang lain juga memiliki hak yang sama. Hal ini begitu relevan karena seringkali dalam permainan kekuasaan, orang tidak segan-segan untuk kepentingan dirinya atau kelompoknya, dan akan berefek lanjutan pada kesengsaraan rakyat kecil yang sebenarnya tidak tahu menahu apa-apa. 
Bahkan Schopenhauer mengatakan bahwa kesadaran dan intelek pada dasarnya hanya merupakan permukaan jiwa kita, dibawah intelek sesungguhnya terdapat kehendak yang tidak sadar, suatu daya atau kekuatan hidup yang abadi, suatu kehendak dan keinginan kuat, "kehendak adalah orang kuat yang menggendong orang lumpuh yang melek". Orang yang sedang kelaparan kemudian mencari makanan bukanlah sebuah perbuatan refleks dari akal, tetapi sumber dari perbuatan mereka adalah kehendak yang setengah sadar untuk hidup, mereka didorong oleh apa yang mereka rasakan, yaitu rasa lapar, intelek hanyalah menjadi tangan kanan dari kehendak, alam menciptakan akal sebagai untuk melayani kehendak individu, dan ketika kehendak itu berkuasa, maka disitulah manusia itu "ada", dan dalam konteks ini jika manusia itu lapar kemudian memuaskan laparnya dengan makan maka saat itulah manusia itu "ada" (Fajar, 2017).

Perubahan pola fikir dan kesadaran menjadikan singkong sebagai kebutuhan pokok tentu memiliki landasan filosofis. Menurut Abah Widi (51 tahun) "konservasi tina katuangan hui, nandaskeun tuntunan supados teu tergantung kana kaayaan beas. Ngarubah "pola eumam" nunjuken kakiatan kana awak kahirupan margi tuang dimaknaan sumber kakiatan. Teu dahar asal kiat” (Widi, Filosofi Makan Adat Cireundeu, 2019).

Bagi masyarakat Kampung Cireundeu tanaman singkong memiliki beberapa kelebihan, antara lain : (1) Bisa untuk sumber pangan dan cocok dengan kondisi geografis masyarakat Cireundeu yang berada pada dataran lahan berbukit. (2) Menurut para 'Inohong' (tokoh adat Kampung Cireundeu), singkong itu dianggap sebagai tanaman tidak ber roh. Apa maksudnya? Dalam hal ini yang dicabut/diambil adalah umbinya, sedangkan yang ditanam (ber roh, karena hidup) adalah batangnya. Jadi menurut tokoh adat disini yang ditanam bukan umbinya tetapi batangnya sehingga dianggap tidak ' ber roh'. Berbeda dengan padi ataupun jagung yang dianggap tanaman ber roh, karena yang ditanam untuk hidup adalah bijinya (Fadhilah, 2014).

Pola fikir ini semakin menguatkan karakteristik masyarakat Cireundeu. Makan tidak hanya dimaknai konsumsi asupan beras atau kebutuhan pokok semata. Yang paling mendasar sesungguhnya makna makan adalah sumber kekuatan. Sekalipun tidak makan, asal kuat maka sesungguhnya disitulah esensi makan. Oleh karenanya, makan atau diistilahkan tuang merupakan refleksi kemandirian kampung Cireundeu dalam menghadapi fluktuasi harga beras yang tidak menentu. Di samping ada dimensi kepasrahan, ketika harus dihadapkan pada globalisasi sosial terutama berhadapan dengan masyarakat sekitar yang menjadikan beras sebagai kebutuhan pokok. Bisa dipastikan, konsumsi tuang singkong bukan sekedar tradisi bahkan berada pada tingkatan level ritual, sebab ada sugesti keyakinan bahkan ada sangsi adat yang melingkupinya. Dalam menjaga tradisi tuang singkong sekaligus menangkal budaya luar yang secara perlahan mempengaruhinya, 
masyarakat Cirendeu melakukan 4 tahapan;

1. Pasrah sebagai suatu hukum yang harus dipatuhi sebagai anggota kampung adat

2. Pelaksanaan ritual sebagai bagian menjaga tradisi

3. Melestarikan kaulinan sebagai fase pelatihan kejujuran, kedisiplinan, kerjasaman, dan kreatif khususnya bagi generasi muda kampung adat

4. Mengadakan riuangan yang dilakukan setiap malam minggu untuk membangun komunikasi anggota dalam menjaga kelestarian adat (Ogi, 2019).

Sebagai sebuah produk budaya, karakter tuang bisa dimaknai sebagai konsep budaya turun temurun yang menjadi pola tingkah laku yang terikat kepada kelompok-kelompok tertentu, yaitu menjadi adat istiadat (customs) atau cara kehidupan (way of life) manusia (Harris, 1969). Terbukti, tradisi ini melekat pada budaya masyarakat Cireundeu sampai saat ini. Westwood memandangnya sebagai prioritas pengembangan enam pendidikan karakter melalui; trustworthine (rasa percaya diri), respect (rasa hormat), responsibility (rasa tanggung jawab), caring (rasa kepedulian), citizenship (rasa kebangsaan), fairness (rasa keadilan) (Suparlan, 2017).

Unsur-unsur tersebut nampaknya melekat pada karakteristik masyarakat adat Cireundeu dalam memegang teguh tradisi. Sebuah tradisi yang terjaga sebagai bagian dari hakikat kehidupan-nya, menjelma membentuk nilai-nilai spiritualitas masyarakat kampung adat Cireundeu. Spiritualitas yang nampaknya dimaknai sebagai kesadaran manusia akan adanya relasi manusia dengan Tuhan atau sesuatu yang dipersepsikan sebagai sosok transenden. Spiritualitas yang kemudian menumbuhkan kesadaran masyarakat akan adanya hubungan dengan Tuhan, yang diekspresikan dalam kehidupan sehari-hari mereka.

Nilai-nilai sprituliats tuang, dimaknai bagi masyarakat adat Cireundeu bahwa pada makanan itu ada aspek ruhiyahnya. Bukan sekadar kelezatan materinya. Karena itu, hakikat kekuatan diri tidak didasarkan pada apa yang dikonsumsi. Namun akan bernilai pada hakikat makna dan tujuan hidup sehingga memunculkan rasa tanggung jawab memahami eksistensinya menjalankan kewajiban merawat tradisi adat.

Akhirnya, tuang bagi masyarakat kampung adat Cireundeu bukan sekedar hajat konsumsi jasmaniah. Tapi sumber kekuatan yang menjadi tradisi adat. Sepanjang ada kekuatan, maka tuang bukan keharusan. Tuang membawa makna mendalam membawa misi spritualitas dalam membangun karakter pasrah atas keadaan diri mempertahankan godaan manusia dari dua hal; si ujang (duit), si nyai (beras). Si ujang dimaknai, orientasi materialisme sedini mungkin dihindari agar tidak menimbulkan kontaminasi pemikiran yang mengakibatkan kehidupan terpacu pada aspek duniawi. Sedangkan si nyai dipersepsikan nilai budaya karuhun tetap dipelihara untuk menjaga keunikan dan keutuhan institusioliasasi budaya adat dari kepunahan. 


\section{SIMPULAN}

Rasa lapar adalah laksana bumbu bagi orang-orang beriman, sarana penguat untuk jiwa, makanan bagi hati, dan penunjang kesehatan badan. Oleh karena itu, esensi utama dari makan adalah untuk bertahan hidup. Makan untuk hidup bukan hidup untuk makan. Hakikat makan bagi masyarakat Cireundeu adalah kekuatan dengan diistilahkan teu dahar asal kuat. Kekuatan menjadi sumber kehidupan membawa misi keyakinan spiritualitas diri. Disamping itu, hakikat tuang refleksi kemandirian kampung adat dalam menyiasati fluktuasi ekonomi khususnya harga beras yang tidak menentu, sehingga nilai budaya adat tetap terjaga.

Dimensi tuang memiliki makna spritualitas. Penghayatan relasi alam dan spiritualitas menciptakan keyakinan bahwa tingkat spiritualitas tinggi akan berwujud dalam menjaga kelestarian alam. Apabila ritus kelestarian alam ini tidak dilakukan, keyakinan akan kutukan roh nenek moyang akan mengahantauinya. Harmonisasi alam dan spiritualitas menjadikan karakateristik tuang bertumpu pada nilai kearifan lokal disertai keyakinan bagian dari ritus adat yang harus mentradisi. Sekalipun pada dasarnya masyarakat Cireundeu penganut sunda wiwitan, namun dalam filosofi tuang ini berkorelasi dengan pandangan Islam yang menegaskan bahwa seorang hamba Allah demi menjaga kesehatan tubuhnya dan makanan termasuk rezeki yang dilimpahkan Allah kepada-Nya sehingga ia menerima dan menikmatinya dengan penuh rasa syukur.

\section{DAFTAR PUSTAKA}

Ambarwangi, Sri; Suharto. (2014). Reog as Means of Students Appreciation and Creation in art and Culture based on The Local Wisdom . Jurnal Harmoni, Jurnal of art Reseach and Educcation, 40.

Creswel, J. W. (2009). Research Design Qualitative Quantitative and Mixed Method Aproaches. Califomia: Sage Publications.

Daeng, H. I. (2002). Manusia, Kebudayaan, dan Lingkungan : Tinjauan Antropologi. Yogyakarta: Pustaka Pelajar.

Depdikbud. (2005). Kamus Besar Bahasa Indoenesia. Jakarta: Depdikbud.

Douglas, J. (1981). introduction to Sociology; Situation and Stuctures. New York: The Free Press.

Fadhilah, A. (2014). Budaya Pangan Anak Singkong dalam Himpitan Modernisasi Pangan: Eksistensi Tradisi Kuliner Rasi (Beras Singkong) Komunitas Kamopung Adat Cireundeu Leuwi Gajah Cimahi Selatan Jawa Barat. Jurnal Al-Turas, 11-23.

Fajar, F. (2017, April 11). Saya Lapar Maka Saya Makan. Diakses tanggal 17 Maret 2019darihttp://nfprasetyo.blogspot.co.id/2010/04/filsafat-fajar-saya-lapar-m aka-saya.html 
Foster. George M, Barbara Gallatin Anderson. (1986). Antropologi Kesehatan. Jakarta: UI Press.

Gulfa, R. P. (2015). Kajian Desa Swasembada Pangan Berbasis Kearifan Budaya Lokal (Studi kasus Kampung Adat Cireundeu, Kecamatan Cimahi Sselatan, Kota Cimahi). Bandung: Unisba.Repository.ac.id.

Gunardi, Gugun; Mahdi, Sutiono; Ratnasari, Dewi; Sobarna, Cece. (2015). Toponimi dan Lingkungan Hidup Kampung Adat di Tatar Sunda. Proceeding SENARI, 369-374.

Gustiani, Herawati Murti; Utami, Dian. (2017). Strategi Kesantunan Negatif pada Masyarakat Kampung Adat Cireundeu. The 1st Education and Language International Conference Proceedings Center for International Language Development of Unissula (hal. 376-384). Semarang: Unissula Press.

Harris, M. (1969). Monistic Determinism: Anti service. Shoutwestern Journal Antrhopology, 198-206.

Jajat. (2019, Maret 25). Makna "Pamali". (Mumin, Pewawancara)

Mardimin, J. (1994). Jangan Tangisi Tradisi: Transformasi Budaya Menuju Masyarakat Indonesia Modern. Yograkarta: Kanisius.

Meliono-Budianto, V. I. (2004, Agustus). Dimensi Etis terhadap Budaya Makan dan Dampaknya pada Masyarakat. MAKARA, SOSIAL HUMANIORA, VOL. 8, NO. 2, 65-70.

Muhakamurrohman, A. (2014). Pesantren: Santri Kyai dan Tradisi, 2014. Jurnal Ibda: Jurnal Kebudayaan Islam, 114-115.

Nasution, S. (2003). Metode Penelitian Naturalistik Kualitatif. Bandung: Tarsito.

Nurhayanto, Puji; Wildan, Dadan; Alia, Mirna Nur. (2016). Transformasi Nilai-Nilai Kearifan Lokal Masyarakat Adat Cireundeu. Jurnal Sosietas.

Ogi. (2019, Maret 26). Makna Tradisi Tuang. (Mumin, Pewawancara)

Putranto, Keik; Taofik, Ahmad. (2014). Pola Diversifikasi Konsumsi Pangan Masyarakat Adat Kampung Cireundeu Kota Cimahi Jawa Barat. Jurnal Istek, 159-181.

Sabana, S. (2007). Nilai Estetis Pada Kemasan Makanan Tradisional. ITB J. Vis. Art., Vol. 1 D, No. 1, 10-25.

Siena, P. (2017). Filsafat Makan. Diakses tanggal 15 April 2019 dari http://peter-sina.blogspot.co.id/2012/03/filsafat-makan.html

Silalahi, J. (2006). Makanan Fungsional. Yogyakarta: Kanisius.

Soekanto, S. (1987). Sosiologi suatu Pengantar. Jakarta: Rajawali Press.

Suparlan. (2017). Pendidikan Karakter dan Kecerdasan Ganda. Diakses tanggal 15 April 2019 dari http:www. suparlan.com

Widi, A. (2019, Maret 26). Filosofi Makan Adat Cireundeu. (Mumin, Pewawancara). 